\title{
Performance of Urban Infrastructure: Road User Satisfaction Index in Satellite City
}

\author{
Resdiansyah \\ Pembangunan Jaya Center for Urban Studies \\ Universitas Pembangunan Jaya \\ Tangerang Selatan, Indonesia \\ resdiansyah.mansyur@upj.ac.id \\ Tri Nugraha Adikesuma \\ Civil Engineering Department \\ Universitas Pembangunan Jaya \\ Tangerang Selatan, Indonesia \\ tri.nugraha@upj.ac.id
}

\author{
Fredy Jhon Philip.S \\ Civil Engineering Department \\ Universitas Pembangunan Jaya \\ Tangerang Selatan, Indonesia \\ fredy.jhon@upj.ac.id \\ Nailah Nahdiyah \\ Civil Engineering Department \\ Universitas Pembangunan Jaya \\ Tangerang Selatan, Indonesia \\ nailah.nahdiyah@upj.ac.id
}

\begin{abstract}
The rapid growth of Satellite City in South Tangerang will directly impact road infrastructure and environmental conditions. The purpose of this paper is to investigate the performance of existing road infrastructure. The study was to gain the perception of road users regarding various elements of satellite city self-reliance in maintaining the quality of road infrastructure for the Central Business District (CBD) area. Using one of Satellite City in South Tangerang as a case, the specific research objectives are to: ascertain road users level of satisfaction with the road infrastructure such as road features, road drainage system and environment; find out problems faced by road users when using the road infrastructure; determine the most dominant factors affecting road users satisfaction; and develop a road user satisfaction index (RUSI) to measure the road performances. A questionnaire survey was conducted on road users in three selected roads in Satellite City. Through a random sampling, a total of 384 responses were collected. Data processing using SPSS software version 20.00 through Cronbach Alpha ( $\alpha$ ) statistical method and Importance Performance Matrix Analysis (IPMA) has been applied to know the level of satisfaction and importance user. Overall, the user satisfaction index for three road segments in Satellite City is still at a good level with the overall score reaching 2.851 and has not yet reached a very satisfying level (score above 4.0).
\end{abstract}

Keywords: satellite city, road user satisfaction index, Importance Performance Matrix, urban infrastructure

\section{INTRODUCTION}

Indonesia still faces a very urgent challenge in accelerating infrastructure development with the low quality of existing infrastructure. This is indicated by the low Indonesian infrastructure index compared to other ASEAN countries. Based on the 2018 Global Ranking Logistic Performance Index (LPI), Indonesia's infrastructure quality index is ranked 46th in the world, up from the previous 63 in 2018 [1]. But Indonesia's infrastructure quality ranking is still below Singapore (7), Malaysia (41), Thailand (32) and Vietnam (39). On the other hand, according to the Global Mobility Report 2017, the quality of roads in Indonesia is ranked 80 with a value of 3.72 (Number $1=$ Worst, Number 7 = Best). This makes a serious concern for the central government, districts, cities and also satellite city authority to work together to improve the performance and quality of roads in Indonesia. As one of the largest economies in Southeast Asia, the quality of existing infrastructure is inadequate.

However, Indonesia's infrastructure development is not an easy task. The government cannot do it alone. The role of the private sector in infrastructure development will accelerate Indonesia's global competitiveness. One of the roles of the private sector is the development of independent infrastructure such as in satellite cities in Indonesia, among others; Bintaro Jaya, Bumi Serpong Damai (BSD), Alam Sutera, Summarecon City, and the latest Meikarta City. Furthermore, infrastructure development including roads which are the main needs in a satellite city must have a good level of performance and satisfaction. Most of these satellite cities that have the best infrastructure including roads is located in South Tangerang. Rapid City growth will directly have an impact on road conditions and the environment. An independent satellite city may have a good level of satisfaction from the road users. Therefore, it is necessary to conduct a study on the Road User Satisfaction Index (RUSI) for the Satellite City region in terms of maintaining the quality of their roads. This research is expected to produce several outcomes such as the perceptions, experiences and expectations of road users and other stakeholders regarding various attributes of road infrastructure in Satellite City to maintain the quality of road infrastructure.

The purpose of this study is to identify various parameters that affect satisfaction among road users as a whole. Specifically, this study aims to design and develop a Road User Satisfaction Index (RUSI) that reflects the quality and performance of roads in Satellite City which in this case are represented by roads of types I, II and III. To follow the globalization progress, it is required more and more to satellite city authority that they seek best strategies that maintain their good infrastructure in the competitive market of the satellite city development. Associated with good infrastructure is the quality of services provided. The satisfaction appears as one of the most important resources available to the companies always bearing in mind to achieve and enhance competitiveness and ensure the long-term success in environments more than more competitive and more demanding customers [2]. In this framework, we are going to describe the management tool adapted developed by 
Martilla and James [3], where these authors measure the Importance vs. Performance of the company. This tool, Importance-Performance Matrix Analysis (IPMA), has been used in service industries as travel and tourism, education, hospitals and other sectors [3]. Importance Performance Matrix Analysis (IPMA) is widely used in analytical techniques that produce a formula for managing customer satisfaction management [4]. IPMA is a two-dimensional grid-based on comparing performance with the importance which will then be plotted on a Cartesians diagram consisting of four quadrants as shown in Fig. 1 [3]. Each quadrant describes the occurrence of a condition that is different from the other quadrant.

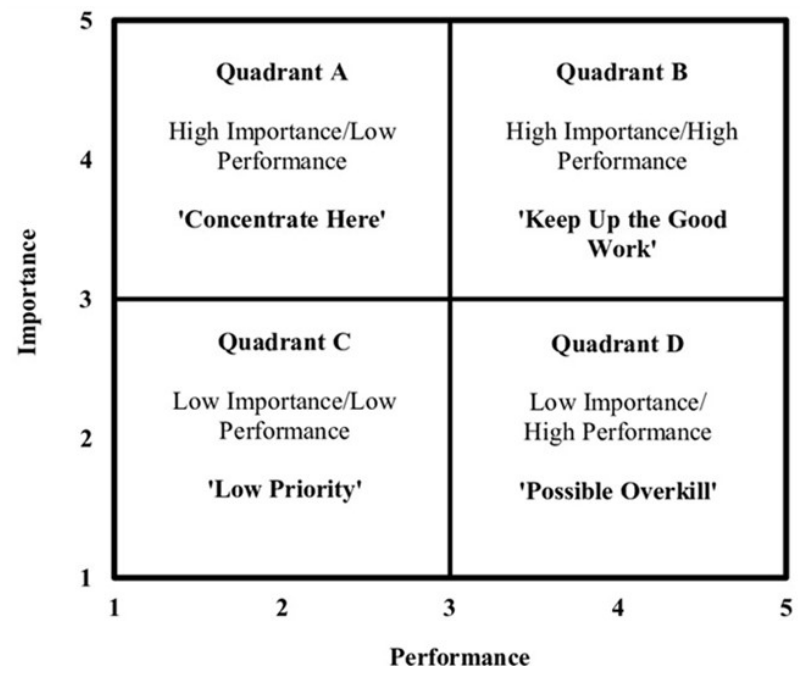

Fig. 1. Importance vs Performance Matrix.

Therefore, in Fig. 1, the Cartesian system is obtained four quadrants that allow set out four distinct strategies [3], namely; quadrant A - Concentrate Here; quadrant B - Keep up the Good Work; quadrant C - Low Priority and quadrant D - Possible Overkill.

\section{Methodology}

The methodology used is the distribution of the questionnaires to users who traveling on the CBD using a Likert scale indicator. Likert scale is used to measure attitudes, opinions, and perceptions of a person or group of people about social phenomena. With a Likert scale, the variables to be measured are translated into variable indicators. Then the indicator is used as a benchmark for compiling instrument items that can be in the form of questions or statements.

\section{A. Random Samples}

Population is an object that is overall used for research. So if there is someone who wants to examine all the characteristics and elements in a research area, of course, the research is included in population research [5]. Then there is a sampling technique which is a simple method of taking samples from the population randomly regardless of the strata that exist in that population. By using the random sample method, 348 people were chosen as respondents with a significant level of $5 \%$.

\section{B. Cronbach's Alpha Method}

The Cronbach Alpha method is used to test survey results that do not have a choice of 'right' or 'wrong' or 'yes' or 'no' but are used to measure attitudes or behavior. This technique is used to determine whether the research instrument is reliable or not, if the answers given by respondents are in the form of scales such as 1-5, the respondent's answers express as follows: [6]

- Very Satisfying $(B C)=5$

- Satisfying $(\mathrm{M})=4$

- $\operatorname{Good}(\mathrm{N})=3$

- $\quad$ Not Satisfying $(\mathrm{TM})=2$

- Very Not Satisfying $(\mathrm{STM})=1$

A reliability test will be conducted to see both the consistency and stability of the data collected. This is necessary because it is important to check whether the data used were reliable or not. The Cronbach's Alpha method will be used to test the reliability or internal consistency of the items that are used to measure the detailed attributes of each of the unique road components.

\section{RUSI Survey}

The RUSI survey for Satellite City is divided into targets/respondents grouped into three different groups (Fig. 2), namely:

- Motorized Road Users

- Non-Motorized Road Users

- Stakeholder Groups / Associations

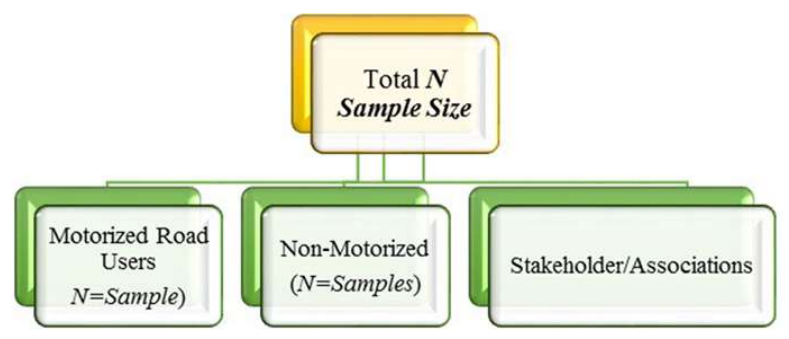

Fig. 2. Planning Sample Distribution Size.

\section{RUSI Elements}

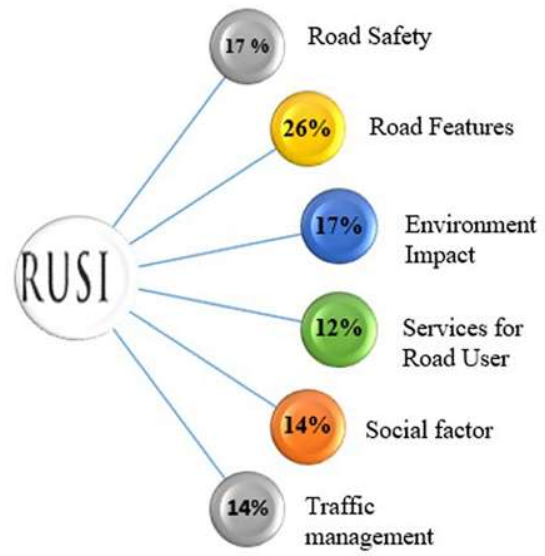

Fig. 3. RUSI Elements Composition. 
The overall measure of road user satisfaction is expressed in a score of 5 and is referred to as the Road User Satisfaction Index (RUSI). There are six elements involved in the overall RUSI index expressed in percentages as shown in Fig. 3.

\section{E. Hierarchy Structure of Outcomes Area and Attributes}

The attributes of the questionnaire will be combined into several groups on a similar topic as shown in Fig. 4. At the end of each group attribute, respondents will be asked to assess how satisfied they are with the aspects of the road system. After all group attributes are discussed, respondents will again be asked to consider all the things discussed and assess their overall satisfaction with the road system. The overall average performance score for the road system will then be calculated. The result will be called a 'RUSI' score. The RUSI score will also be assessed to determine the important supporting factors for the overall satisfaction index.

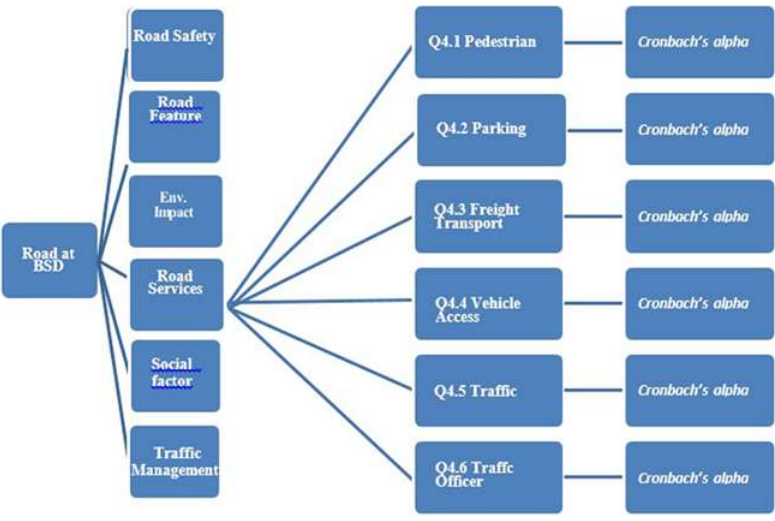

Fig. 4. Road Features Hierarchy of Outcomes Area and Attributes.

\section{RESULTS AND DISCUSSION}

In this study three road locations were selected in the South Tangerang District as sown in Fig. 5.

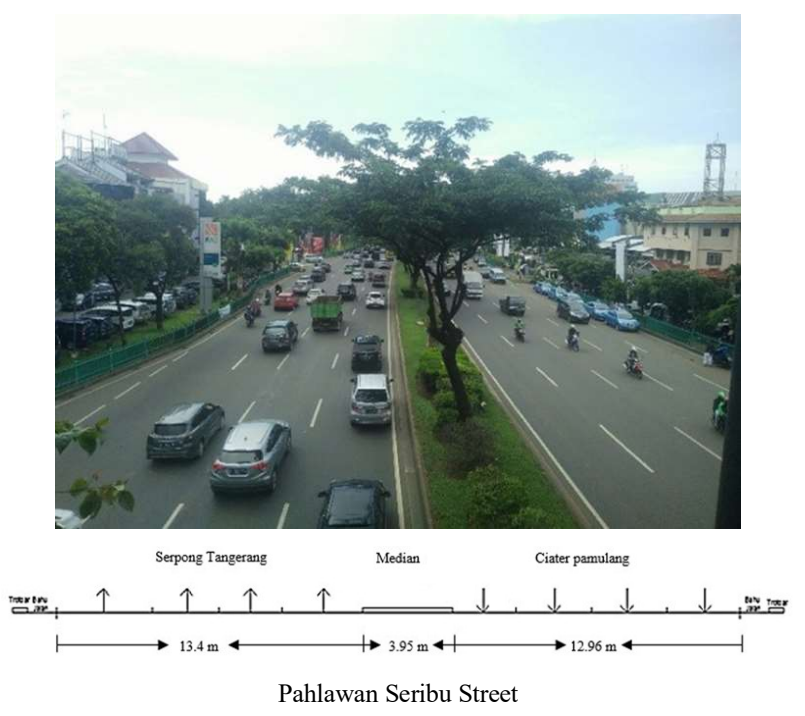

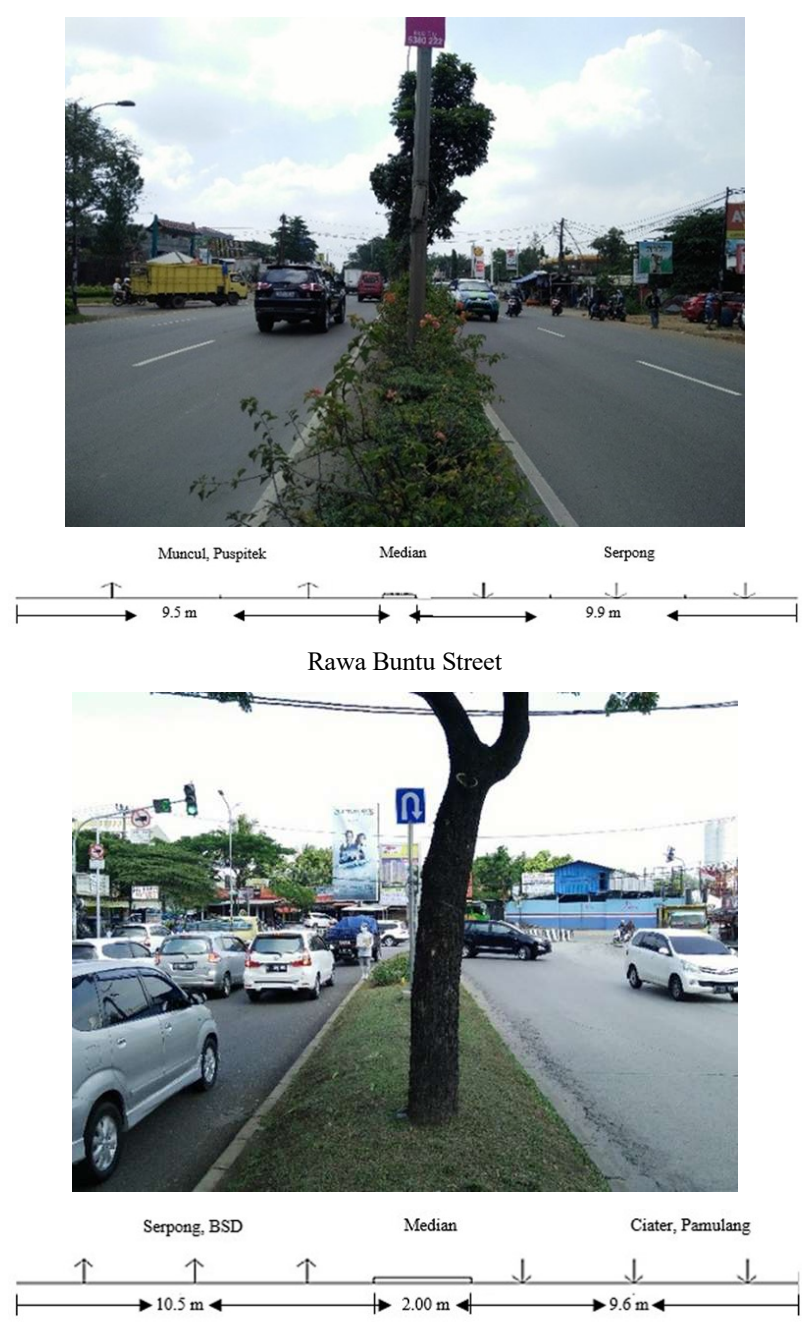

Linkar Timur Street

Fig. 5. Road Geometric Measurement.

\section{A. Validity Test of Pilot Survey}

TABLE I. VALIDITy TeSt OF PILOT SURVEY

\begin{tabular}{|l|l|l|l|l|}
\hline \multirow{2}{*}{ No } & \multirow{2}{*}{$\begin{array}{c}\text { RUSI } \\
\text { Elements }\end{array}$} & \multicolumn{2}{|c|}{ Validity Test } & \multicolumn{1}{|c|}{ Reliability Test } \\
\cline { 3 - 5 } & Valid $\mathbf{8 . 6 3 2}$ & $\begin{array}{c}\text { Not } \\
\text { Valid }< \\
\mathbf{0 . 6 3 2}\end{array}$ & $\begin{array}{c}\text { Cronbach Alfa } \\
(\boldsymbol{\alpha}) ; \text { reliable }> \\
\mathbf{0 . 6}\end{array}$ \\
\hline 1 & Road Safety & 7 & 12 & 0.737 \\
\hline 2 & $\begin{array}{l}\text { The Road } \\
\text { Feature }\end{array}$ & 8 & 19 & 0.861 \\
\hline 3 & Environment & 4 & 3 & 0.751 \\
\hline 4 & $\begin{array}{l}\text { Road User } \\
\text { Services }\end{array}$ & 1 & 6 & 0.335 \\
\hline 5 & $\begin{array}{l}\text { Social } \\
\text { Factor }\end{array}$ & 2 & 4 & 0.326 \\
\hline 6 & $\begin{array}{l}\text { Traffic } \\
\text { Management }\end{array}$ & 5 & 6 & 0.847 \\
\hline
\end{tabular}

The results of validity and reliability tests for 10 respondents in the pilot survey (TABLE I) shows that out of 50 questions in the 6 RUSI elements, there were only 27 valid questions. This validity test is done to ensure those 
questionnaire items are sufficient, correct, and understandable.

In the pilot survey, it was understood that many questions would bring the main research to failure so that the questionnaire was revised with a language that was easier to understand or by eliminating the question.

TABle II. VAlidity Test of Pilot Survey After Revised

\begin{tabular}{|l|l|l|l|l|}
\hline \multirow{2}{*}{ No } & \multirow{2}{*}{$\begin{array}{c}\text { RUSI } \\
\text { Elements }\end{array}$} & \multicolumn{2}{|c|}{ Validity Test } & \multicolumn{1}{c|}{ Reability Test } \\
\cline { 3 - 5 } & Valid $\mathbf{8 . 6 3 2}$ & $\begin{array}{c}\text { Not } \\
\text { Valid }< \\
\mathbf{0 . 6 3 2}\end{array}$ & $\begin{array}{c}\text { Cronbach Alfa } \\
(\boldsymbol{\alpha}) \text { : } \text { reliable }> \\
\mathbf{0 . 6}\end{array}$ \\
\hline 1 & Road Safety & 7 & 12 & 0.737 \\
\hline 2 & $\begin{array}{l}\text { The Road } \\
\text { Feature }\end{array}$ & 8 & 19 & 0.861 \\
\hline 3 & Environment & 4 & 3 & 0.751 \\
\hline 4 & $\begin{array}{l}\text { Road User } \\
\text { Services }\end{array}$ & 1 & 6 & 0.335 \\
\hline 5 & $\begin{array}{l}\text { Social } \\
\text { Factor }\end{array}$ & 2 & 4 & 0.326 \\
\hline 6 & $\begin{array}{l}\text { Traffic } \\
\text { Management }\end{array}$ & 5 & 6 & 0.847 \\
\hline
\end{tabular}

The test results in TABLE II show that the entire path is valid on all question variables, while the reliability test results are reliable on all question variables.

\section{B. Perception of Road Users Toward Important Ranking of Elements in RUSI}

Fig. 6 explains the perception ranking of road users toward the importance of road elements obtained based on the highest and lowest values. The results are obtained based on respondents' answers by sorting road elements with numbers $1-6$, where 6 is very important and 1 is the least important, it can be seen that road safety and traffic management are the most important elements based on user perceptions, which are $21 \%$ and $20 \%$.

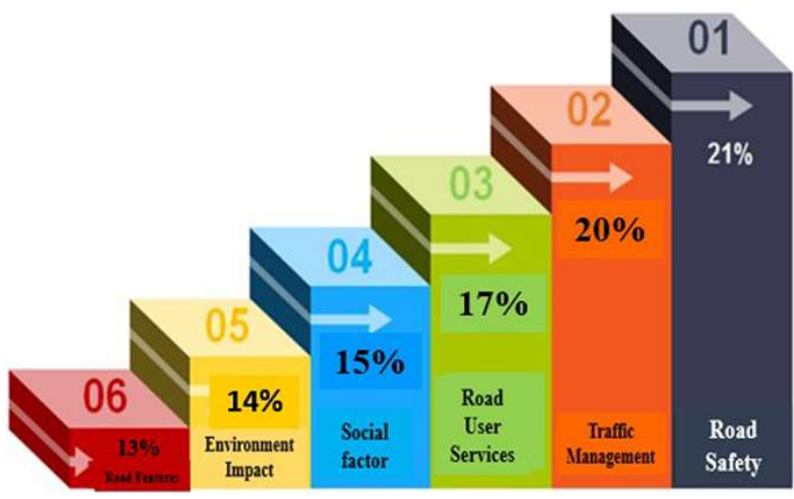

Fig. 6. Perception of Road User Pahlawan Seribu Street.

Fig.7 shows the highest importance on Rawa Buntu Street is $22 \%$ and the results are obtained on the road safety element, followed by $19 \%$ for traffic management.

Slightly different from the previous two roads, the highest importance of user perception in this road section (Fig.8) has been obtained at $21 \%$ for traffic management followed by environmental impact at $19 \%$. Traffic safety was ranked 4th with $16 \%$, and services for road users reached $17 \%$. This is because Lingkar Timur Street requires better traffic engineering considering that it is the main ring road in a satellite city.

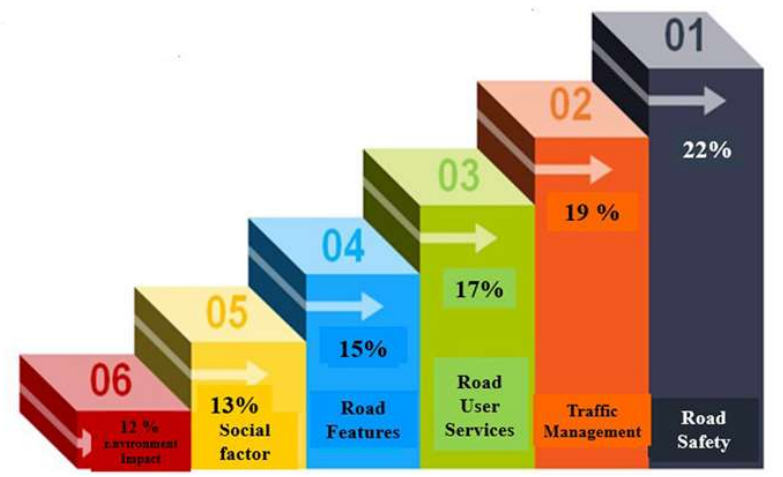

Fig. 7. Perception of Road User Rawa Buntu Street.

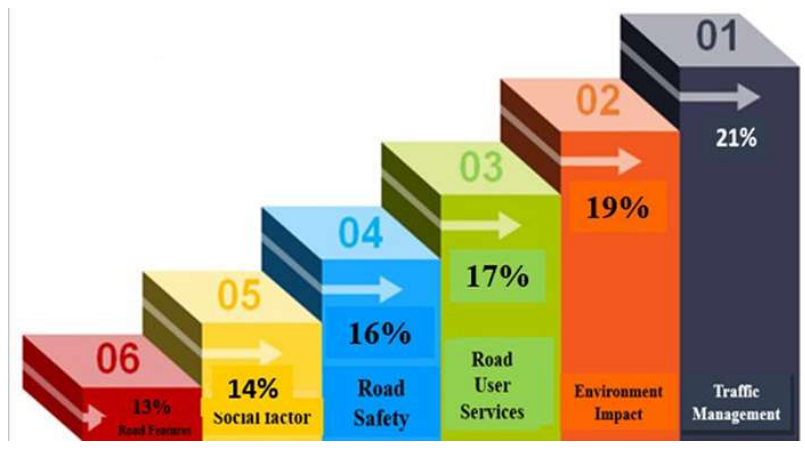

Fig. 8. Perception of Road User Linkar Timur Street.

\section{Road User Satisfaction Index Equations}

Based on the results of the processed data (TABLE III), the satisfaction index obtained for the three roads as below:

TABLE III. RUSI OVERALL RESUlts

\begin{tabular}{|c|c|c|c|}
\hline No & Road Name & RUSI & \\
\hline 1 & Pahlawan Seribu (Type I) & & \multirow{7}{*}{3.098} \\
\hline & Road Safety & 3.027 & \\
\hline & The Road Feature & 3.250 & \\
\hline & Environment & 3.270 & \\
\hline & Road User Services & 3.050 & \\
\hline & Social Factor & 3.030 & \\
\hline & Traffic Management & 2.960 & \\
\hline \multirow[t]{7}{*}{2} & Rawa Buntu (Type II) & & \\
\hline & Road Safety & 2.536 & \\
\hline & The Road Feature & 2.669 & \\
\hline & Environment & 2.573 & \\
\hline & Road User Services & 2.570 & \\
\hline & Social Factor & 3.297 & \\
\hline & Traffic Management & 2.541 & 2.698 \\
\hline \multirow[t]{8}{*}{3} & Linkar Timur (Type III) & & \\
\hline & Road Safety & 2.652 & \\
\hline & The Road Feature & 2.714 & \\
\hline & Environment & 2.831 & \\
\hline & Road User Services & 2.660 & \\
\hline & Social Factor & 3.167 & \\
\hline & Traffic Management & 2.526 & 2.758 \\
\hline & & $\begin{array}{l}\text { Overall } \\
\text { RUSI }\end{array}$ & 2.851 \\
\hline
\end{tabular}




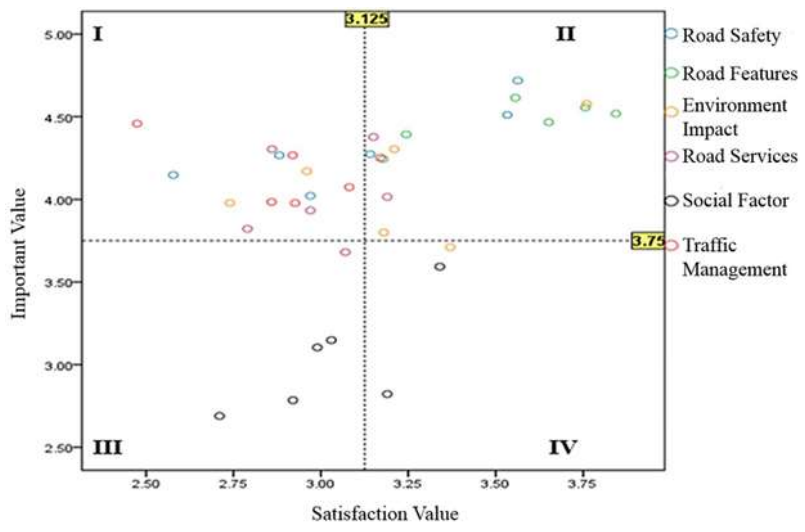

Fig. 9. IPMA Pahlawan Seribu Street

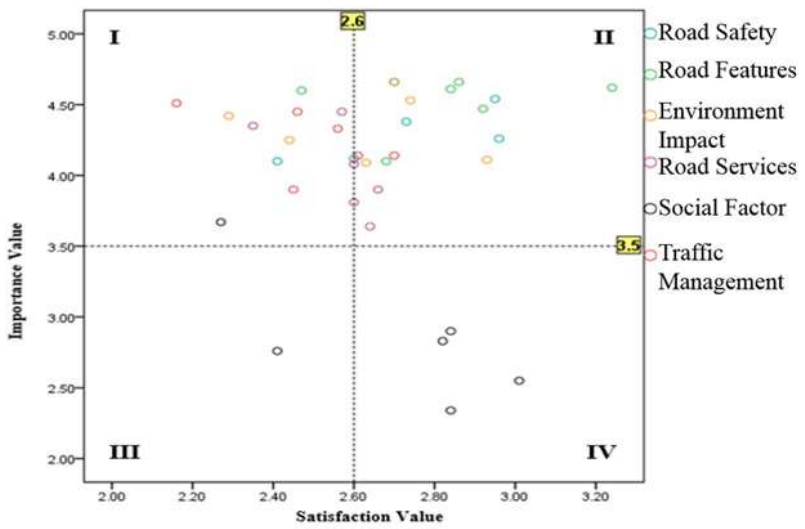

Fig. 10. IPMA Rawa Buntu Street

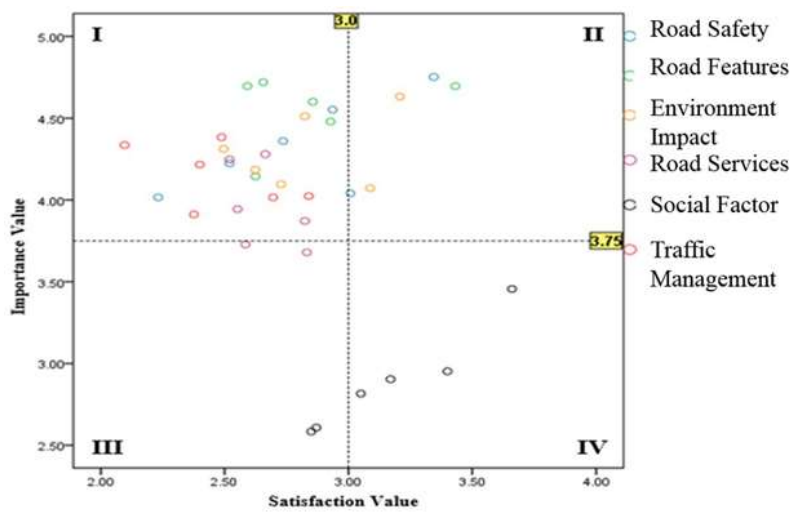

Fig. 11. IPMA Linkar Luar Street

From the results of the importance and satisfaction level, then the data is transferred in the form of IPMA matrix in four quadrants as shown in Fig. 9 until Fig. 11.

The IPMA matrix show that for both road sections, Pahlawan Seribu and Rawa Buntu Road, there are still elements that must be improved in terms of performance, namely traffic management, services for road users and road safety. Besides, some elements must be maintained, namely road features and environmental impacts. On the other hand, for Linkar Timur Road, results of the matrix value indicate that there are elements that must be improved such as traffic management, road features, and road safety. Besides, some elements must be maintained, namely environmental impact.

\section{CONCLUSIONS}

Overall, the user satisfaction index for three road segments in Satelite City is still in "good level" with the overall score reaching 2.851 and has not yet reached a "very satisfying level"'(score above 4.0), but when viewed based on class I road type, Pahlawan Seribu Road reaches a level of satisfaction "very good", with a score of 3.098 , especially for road features and environmental impacts which reached 3.25-3.27.

This is because the road is the main arterial segment in Satelite City. As for the other two roads, some elements need to be improved because they reach a low satisfaction index of around 2.6-2.8.

\section{ACKNOWLEDGMENT}

This research is fully supported under the research fund Number: 001/PER-P2M/UPJ/10.17 from LP2M (Research and Community Service Centre), Universitas Pembangunan Jaya, Indonesia. Besides, the authors would like to acknowledge the Mayor of South Tangerang City for their assistance in collecting data and would like to acknowledge the support form and Pembangunan Jaya Centre for Urban Studies.

\section{REFERENCES}

[1] S. Arikunto, "Research procedure: Practical approach". 5th Edition. Publisher: Rineka Cipta. Jakarta. 2002.

[2] I. Rigopoulou, I. Chaniotakis, C. Lymperopoulos, and G. Siomkos, "After-sales service quality as an antecedent of customer satisfaction: The case of electronic appliances". Managing Service Quality, vol. 18, No.5, 2008, pp. 512-527.

[3] H.P. Ferreira and P.O. Frenandes, 'Importance-performance Analysis Applied to a Laboratory Supplies and Equipment Company", Procedia Computer Science Vol. 64, 2015, pp. 824-831.

[4] Sabri Ahmad and Wan Mohamad Asraf, "The Importance Performance Analysis in Partial Least Square Structural Equation Modelling (PLS-SEM) with SMARTPLS 2.0 M3". International Journal of Mathematical Research, Vol. 3, No.1, 2014, pp.1-14.

[5] S. Syofian, D. Edwin, and Karino, "Evaluation of Community Satisfaction Level to Road Development at Dwikora District, Sumatera Utara University”, 2015.

[6] World Bank, "Global Ranking Logistic Performance Index (LPI)", 2018, https://lpi.worldbank.org/international/global 